VS Publications

Alford Council of International English \& Literature Journal(ACIELJ)

Impact Factor:4.401(SJIF)An International Peer-Reviewed English Journal

www.acielj.com

Vol-3,Issue-2 ,2020

ISSN:2581-6500

\title{
Bias in African Traditional Judicial System: A Pragmatic Study of Silence in Kunle Afolayan's October $1^{\text {st }}$
}

\author{
Titilope Oluwaseun Oriola \\ Department of English Studies \\ AdekunleAjasin University Akungba-Akoko \\ Ondo State,Nigeria \\ alake.titi@gmail.com
}

\begin{abstract}
African traditional judicial system, including those on judgment enactment on royal lineage,especially in chaotic situations, often evokes bias. Existing studies on traditional judicial system, largely from philosophy, religious studies and legal fields, have focused rather on objective and positive stance but have not accounted for the seemingly bias demeanor of Ifaespecially in cases relating to royal descents, which would have facilitated the background of corrupt practices and judgments in the Nigerian judicial system. This study, therefore, investigates avoidance as a pragmatic strategy of bias inKunleAfolayan'sOctober

necessitating a renegotiation of an existing recommendation of law by Ifa, while the analysis shows that Ifa chronicles, an enshrined rule of law in the African cosmology can be re-negotiated to accommodate certain respected deities/man. The priest's strategy of silence or avoidance strategy in October $1^{s t}$ proves useful in locating agency and responsibility in Ifaverdict and consequently instituting a more effective judicial system in the Nigerian context. The study reveals Ifa'sbias and nongenerality in pronouncing judgment and subsequently punishment, which may generate a complex and precipitate many hazards in the African judicial system.
\end{abstract} $1^{s t}$. The study adopted Jacobson's Eloquence Silence andMey'sPragmeme to investigate instantiation of meanings with reference to cultural relativism. At a more general level, this paper suggests that the pragmatic agenda can be purposefully broadened to investigate the root cause of corruption in the Nigerian judicial context. It argues that avoidance as a strategy deployed by Ifaworshippers is induced in order to regard the kingship who are given honour in the African worship. Negotiation of avoidance as a contextual trigger of African belief and norm is anchored on the Nigerian rule of law

Keywords: Ifa mythology, silence, impunity, kingship, narratology.

\subsection{Introduction}

The African traditional judicial system, though ancient, has a predominant influence on the African, especially on the Nigerian rule of law. This knowledge embodies a wealth of experience used in the modern judicial system. Throughout history, according to Jeffrey (1990) 'cultures all over the world have developed different views of administrations. Many of these measures 
VS Publications

Alford Council of International English \& Literature Journal(ACIELJ)

Impact Factor:4.401(SJIF)An International Peer-Reviewed English Journal

www.acielj.com

Vol-3,Issue-2,2020

ISSN:2581-6500

are subconsciously rooted in traditional systems of beliefs, which indigenous people use to understand and interpret breach in tradition and law. The systems of managing the law often constitute an integral part of the cultural identity and social integrity of many indigenous populations.Traditional Judicial system has been rediscovered as a model for modern interaction with, and as a rich source of history in gaining new perspectives about the relationship between humans and nature; offences and punishment; power relations and immunity. Ifa, a major Yoruba chronicle of law has been chosenviz a viz the modern judicial book of law (rule of law). This is because the credence of Ifaas a major judgement enactment tool of the Yorubasis a body of principles that guide to peaceful co-existence among people of different races and cultures; of Africa and beyond just as the modern rule of law dictates the obligations, rights and offences while bridged.

Researches in modern judicial field have made evident the corrupt practices perpetrated by modern juries and judges alike; thereby hindering free and fair judgment to the poor and subjected. The rule of law gives modern rulers (Presidents, Governors, Senators and Ministers) immunity as the Obasin the ancient African cultures are revered and honored.The present researchintends to reveal that the corrupt modern judicial practices have its history in theAfrican culture of immunity. This study aims at looking at the bias of traditional Ifa oracles (judges) in matters relating to the evil practices of Oba descents therebyexposing the society to evil. The film, October
$I^{s t}$ was chosen purposively because of the testament of Afonja, a police inspector supervising the Akote province that the If $a$ priest (Baba-Ifa) cannot divine against anyone from the Oba's immediate family. Given that the Grecian triangular characterisation, identifies a cast basically by what they say about themselves, what other casts say about them and what they do. It is thus evident that, If $a$ as a character in the movie, October $1^{s t}$ whose statements by its priest(Baba-Ifa) serve as the bedrock of the movie could give bias verdict in situations involving the king's household which would hinder fair judgement.

This study, therefore, investigates avoidance as a major strategy deployed by Baba-Ifawho is in the middle of revering the king's household and given a fair judgment to the benefit of the entire community. By avoidance, we mean Eloquent Silence (Jacobson, 1996). Together with the theory of stance from which silence is selected in the dialogic film space, multimodality is chosen because of the pictures and images. The research intends to take a cursory look at all instances of eloquent silence, especially that of the Ifapriest and explain their pragmatic implications.

\subsection{History of Criminal Justice}

Jeffrey (1990) defines criminal justice as a system used by government to maintain social control, prevent crime, enforce laws and administer justice. Such law enforcement agencies as the police, and the courts are primarily charged with the responsibilities of maintaining peace in the society. He asserts that the pursuit of criminal justice is, like all forms of 
VS Publications

Alford Council of International English \& Literature Journal(ACIELJ)

Impact Factor:4.401(SJIF)An International Peer-Reviewed English Journal

www.acielj.com

Vol-3,Issue-2,2020

ISSN:2581-6500

"justice," predicated on 'fairness' or due process which is essentially the pursuit of an ideal.Modern criminal justice evolves from the traditional or ancient times. These developments or evolvements are reflected in changing customs, political ideals and economic conditions (Jeffery, 1990). From the ancient times through the middle age, such punishments as banishment, fine payment etc. were common punishments enacted on law breakers. But for corporal crimes, offenders were subjected to various forms of harsh punishments, such as mutilation, branding, burying alive etc.but not without showing some regards to the Oba's family. kings' kinsmen were given lesser punishment. This is because in most of the African societies, ancestors were greatly reverenced and conceived as gods possessing spiritual powers. An example of this is the Ooni of Ife who is considered one of the 201 deities in the Yoruba mythology and thus worshipped once in a year in the Ife Ooye. According to an Arokin(a historian in the king's courtyard) the Ooni should neither be seen while sitting down nor eating because of his position as a god.

Elias (1953) did an investigation on the Nigerian legal system with specific emphasis on the mischief of the Nigerian jury system, and the elements of Nigerian law. Mekonnen (2008) queries the role of indigenous legal tradition (ILT) in contemporary African transitional justice initiative. Given that the Obas in the Yoruba parlance are gods and also recognized in the British Government as identified by Achara (1981) who traced the sources of Nigerian law and classified them into: local laws and customs, English common law, doctrine of English equity and the statutes of general application; local legislation and the interpretation based thereon; law reports; textbooks and monographs on Nigerian law; judicial precedents. He found out that the British administration of Nigeria gave statutory recognition to Nigerian laws and customs by making provision in section 20 of the supreme court ordinance for the application of the local laws and customs. It is on the premise of what Achara (1981) called the structural dependence of foreign policy that the current research intends to trace the corrupt practices of modern law to the indigenous laws in order to suggest corrective measures.

\subsection{Review on Nollywood}

Olayiwole (2016) worked on

demythologization

in

KunleAfolayan'sFigurineand concludes that like Femi Osofisan, Afolayandemystifiesand demythologises sacred matters; like gods involving in the activities of mankind. Such Osofisan's plays as No Longer a Wasted Breed, Morountodun, Once Upon Four Robbers amongst others show that some African mythologies are mere coincidence. Olayiwole faults this claim and advocates that the gods are very much enshrined in the heart of every matter.Oladipo (2002) Worked on the experimentation of differentiation of film making strategies that are aesthetically sophisticated. And pointed out that a new era of film making in Nigeria is ushered by a high level of sophistication and technology. This is a new era of sophistication in the Nollywoodappeal to the senses of their viewers. Amongst the evolving and new trend of filmmakers is KunleAfolayan. 
VS Publications

Alford Council of International English \& Literature Journal(ACIELJ)

Impact Factor:4.401(SJIF)An International Peer-Reviewed English Journal

www.acielj.com

Vol-3,Issue-2,2020

ISSN:2581-6500

\subsection{Indigenous Legal Tradition}

Ofin(law) in the traditional Yoruba society cannot be divorced from the moral milieu in which it operated. It operated in a socio-cultural atmosphere dominated by a belief in the existence of supernatural powers and a social structure controlled by a hierarchy of authorities. The 'mythical character' which embodies the traditional Yoruba worldview is Olodumare. OlodumareThusgaveportfolios of power to other gods such as:Obatala who was in charge of creation; Ogun was a warlord and forger of all weapons of war, Esuwas the god of all crafts and knowledge; Orunmila was a guardian of mankind showing them how to behave or propitiate other divinities (Idowu, 2009)

\subsection{About Ifa}

Ifa is a cellar of ancient wisdom. He was one of those who journeyed from Orunto found the Yoruba kingdom of ileife and it was generally believed among the Yorubasand beyond that Ifa is all knowing and guides one in life..Ifáis a religion and system of divination which includes verses of the literary corpus known as the OduIfá (256 chronicles). Orunmila is the grand priest of Ifa and the oracular representative of Olodumare. The Ifa divination is practiced among Yoruba communities and by the African diaspora in the Americas and the Caribbean. Ifa divination makes use of an extensive corpus of texts and mathematical formulas. Its knowledge has been preserved within Yoruba communities and transmitted among Ifa priests from generation to generation (Idowu, 2009). No wonder its guidance was sorted when confronted with a serial murder puzzle.

\subsection{Synopsis of October $1^{\text {st }}$}

The movie opened on a prologue which featured the rape and murder of a young virgin.setting the tone of the film as that of violence and social chaos.Afolayan's October $1^{\text {st }}$ is an award winning movie that delves into African traditional Ifamythology and modern system ofinvestigation. The movie was set in a small but peaceful community of Akotewhere education was rated high. Two primary school leavers:KoyaandAderopo were sponsored by Reverend Father Dawlinto further their education in the King's College of Ibadan only to be molested and dehumanized by the well revered Father. Koya returned to the community after four months of torture and molestation but Aderopo who loved education endured and completed his advanced study which lasted for four years. The incessant dehumanization and molestation by Father Dawlin opened up his heart to evil and cruelty.He returned to the village with a heart of revenge and anger;causing him to rape and kill six virgins. He was about to dehumanize the seventh when he was caught. Aderopo was popular amongst his friends in the village not only because he was an educated king, also because of his opinion against the Nigerian independence of 1960 which he referred to as being too early and unprepared for. And insisted that the country would be at war with itself before long because of the varying ethnic groups(Hausa, Ibo and Yoruba) forcefully merged together.

October $1^{\text {st }}$ is an investigative movie that gradually unfolds the horror and loops of the British imperialism. It 
VS Publications

Alford Council of International English \& Literature Journal(ACIELJ)

Impact Factor:4.401(SJIF)An International Peer-Reviewed English Journal

www.acielj.com

Vol-3,Issue-2,2020

ISSN:2581-6500

was a movie of horror, killing, revenge, dehumanization, gayism and unravels the mystery behind the British Colonial Judicial System. The Ifa tradition was magnified in the movie because of its use of deuxmachina(the hands of the gods)

\subsection{Theoretical Framework}

Michal Ephrat reviewed the roles of Eloquent Silence in each of the six functions of language in Roman Jakobson'sCommunicative Model (1960) by differentiating linguistic first from eloquent silence. According to him, pause, being outside language, is different from (eloquent) silence, a means chosen by the speaker for significant verbal communication alongside speech.He further identifiedcertain functions which are evident in the movie. These include: conative, emotive, speech acting, referential, phatic, discourse marker and conceptual.

Conative- This is the use of euphemism especially for respected personalities.

Emotive- Silence is used when words are not weighty enough to express one's mind.

Speech acting- it is used to evoke or create a feeling.

Referential- It is used when a circumstance calls up a memory of something.

Phatic: Silence is a means of maintaining contact and alliance in a social milieu.
Discourse marker- It is a kind of linguistic filler.

Conceptual - A mental feeling

In every instance of human interaction, either in speech or writing pragmatic acts are performed .Mey (2001:214) proposes a theory of action that specifies, for any given situation, the limitations and possibilities of the situation. Because human beings live within social contexts that control their lives and how they use language which is often governed by social values and norms. It thus logically follows that individuals do not speak (i.e perform actions) without reference to the context and the level of freedom or affordances that are allowed by the society to perform such acts. In sum, the pragmatic acting can be considered as adapting oneself linguistically and otherwise to one's world and all our acting is done in that world and within the affordances it puts at our disposal (Mey2001,p.215).

\subsection{Analysis}

The story began on the $5^{\text {th }}$ of September with two successive gruesome rape and murder on the $1^{\text {st }}$ and $3^{\text {rd }}$ ofSeptember. It was after this that the grand welcome party of prince Aderopowas celebrated from the premier college of Ibadan. On the same day, Sergeant Sunday Afonjaand Danladi Waziri were returning from a murder scene. 
VS Publications

Alford Council of International English \& Literature Journal(ACIELJ)

Impact Factor:4.401(SJIF)An International Peer-Reviewed English Journal

www.acielj.com

Vol-3,Issue-2 ,2020

ISSN:2581-6500

\begin{tabular}{|c|c|c|c|c|c|}
\hline Characters & $\begin{array}{ll}\text { Instances } & \text { of } \\
\text { eloquent silence } & \end{array}$ & Function & Pragmatic role & Pragmatic import & $\begin{array}{l}\text { Prag } \\
\text { matic } \\
\text { acts }\end{array}$ \\
\hline Baba-Ifa & $\begin{array}{l}\text { In an interrogative } \\
\text { session with Afonja } \\
\text { and Inspector Waziri } \\
\text { about the serial killer. }\end{array}$ & Conative & Indirect speech & $\begin{array}{l}\text { Baba-Ifa started with a } \\
\text { rendition: 'He is in } \\
\text { turmoil, in pain; He } \\
\text { wants to be free, but he } \\
\text { is indecisive as regards } \\
\text { his course of action, he } \\
\text { will yet commit more } \\
\text { murder.' } \\
\text { That showed the } \\
\text { knowledge of Ifa about } \\
\text { the murder puzzle. } \\
\text { Inspector Afonja then } \\
\text { asked in straight terms } \\
\text { who the killer was. } \\
\text { Baba-Ifa looked } \\
\text { straight at him, shook } \\
\text { his head and walked } \\
\text { away. In Baba-Ifa's } \\
\text { rendition, it was } \\
\text { obvious as pointed out } \\
\text { by inspector waziri that } \\
\text { he knows more than } \\
\text { what he is saying; } \\
\text { obviously flouting the } \\
\text { cooperative maxim of } \\
\text { quantity by saying too } \\
\text { little and choosing to } \\
\text { adopt silence. } \\
\text { The referent of Baba- } \\
\text { Ifa's rendition is } \\
\text { exophoric. }\end{array}$ & $\begin{array}{l}\text { Conce } \\
\text { aling, } \\
\text { evoki } \\
\text { ng, } \\
\text { regard } \\
\text { ing, } \\
\text { desiri } \\
\text { ng }\end{array}$ \\
\hline & $\begin{array}{l}\text { At the king's } \\
\text { courtyard. The chiefs } \\
\text { and the king were } \\
\text { eager to know the } \\
\text { killer }\end{array}$ & $\begin{array}{l}\text { Discourse } \\
\text { marker }\end{array}$ & filler & $\begin{array}{l}\text { He utilized eloquent } \\
\text { silence as a filler. } \\
\text { Traditionally, it is } \\
\text { believed that when } \\
\text { there is a mystery, }\end{array}$ & $\begin{array}{l}\text { Conce } \\
\text { aling, } \\
\text { reques } \\
\text { ting, } \\
\text { acting }\end{array}$ \\
\hline
\end{tabular}


VS Publications

Alford Council of International English \& Literature Journal(ACIELJ)

Impact Factor:4.401(SJIF)An International Peer-Reviewed English Journal

www.acielj.com

Vol-3,Issue-2 ,2020

ISSN:2581-6500

\begin{tabular}{|c|c|c|c|c|c|}
\hline & & & & $\begin{array}{l}\text { elders would think well } \\
\text { before talking. Baba Ifa } \\
\text { thereby utilizing this } \\
\text { knowledge decided to } \\
\text { use this means to } \\
\text { escape the response } \\
\text { expected. }\end{array}$ & $\begin{array}{l}\text { dema } \\
\text { nding }\end{array}$ \\
\hline Aderopo & $\begin{array}{l}\text { At his grand entry } \\
\text { ceremony into Akote } \\
\text { after his graduation }\end{array}$ & Referential & Emotions/hate & $\begin{array}{l}\text { The grand entry } \\
\text { ceremony of Aderopo } \\
\text { into Akote fell on the } \\
\text { day that inspector } \\
\text { Waziri went to check } \\
\text { the murder scenes of } \\
\text { two victims that } \\
\text { happened on the } 1^{\text {st }} \text { and } \\
3^{\text {rd of September }} \\
\text { respectively. This was } \\
\text { the day Aderopo was } \\
\text { welcomed back from } \\
\text { Ibadan. } \\
\text { explained that it was } \\
\text { the prince's return- } \\
\text { party. Waziri greeted } \\
\text { Aderopo but the latter } \\
\text { fixed his gaze on him. } \\
\text { Before muttering: 'you } \\
\text { seem to have travelled } \\
\text { a long way from home. }\end{array}$ & $\begin{array}{l}\text { Dema } \\
\text { nding, } \\
\text { accusi } \\
\text { ng, } \\
\text { conde } \\
\text { mning }\end{array}$ \\
\hline Aderopo & $\begin{array}{lcr}\text { Having } & \text { a } & \text { leisure } \\
\text { stroll } & \text { along } & \text { the } \\
\text { market } & & \end{array}$ & Referential & Pain & $\begin{array}{l}\text { Aderopo came across } \\
\text { Agbekoya, an old } \\
\text { primary school friend } \\
\text { and mate whom they } \\
\text { travelled together to } \\
\text { start school in the } \\
\text { Premier College of }\end{array}$ & $\begin{array}{l}\text { Evoki } \\
\text { ng, } \\
\text { Dema } \\
\text { nding, } \\
\text { shunn } \\
\text { ing }\end{array}$ \\
\hline
\end{tabular}


VS Publications

Alford Council of International English \& Literature Journal(ACIELJ)

Impact Factor:4.401(SJIF)An International Peer-Reviewed English Journal

www.acielj.com

Vol-3,Issue-2 ,2020

ISSN:2581-6500

\begin{tabular}{|c|c|c|c|c|c|}
\hline & & & & $\begin{array}{l}\text { Ibadan but dropped out. } \\
\text { Both of them } \\
\text { maintained eye contact } \\
\text { but never uttered a } \\
\text { word. This shows } \\
\text { mutual understanding } \\
\text { (shared knowledge) of } \\
\text { the killer in the } \\
\text { community. }\end{array}$ & \\
\hline Sunmonu & $\begin{array}{l}\text { When he was } \\
\text { detained for the death } \\
\text { of his lover, Bisi }\end{array}$ & Phatic & Ignorance & $\begin{array}{l}\text { Silence is a means of } \\
\text { maintaining contact and } \\
\text { alliance in the phatic } \\
\text { function. Sunmonu is } \\
\text { illiterate and could not } \\
\text { understand the } \\
\text { allegation against him, } \\
\text { so looks from Waziri's } \\
\text { face to Omololu'sface } \\
\text { for interpretation }\end{array}$ & $\begin{array}{l}\text { Appea } \\
\text { ling }\end{array}$ \\
\hline Tawa & $\begin{array}{l}\text { Inspector Waziri met } \\
\text { with Tawa in school } \\
\text { to know more about } \\
\text { Aderopo'seducational } \\
\text { background }\end{array}$ & Referential & Emotions/love & $\begin{array}{l}\text { Tawa gave sweet } \\
\text { memories of their } \\
\text { schooling together in } \\
\text { the Akote primary } \\
\text { school. }\end{array}$ & $\begin{array}{l}\text { Roma } \\
\text { ncing, } \\
\text { relivin } \\
\mathrm{g}\end{array}$ \\
\hline Omololu & $\begin{array}{l}\text { In the bush when he } \\
\text { realized that Aderopo } \\
\text { is the killer }\end{array}$ & Politeness & Confusion & $\begin{array}{l}\text { Aderopo's use of } \\
\text { eloquent silence is } \\
\text { borne out of confusion. } \\
\text { A prince is revered and } \\
\text { should not be found in } \\
\text { evil doing. }\end{array}$ & $\begin{array}{l}\text { Conde } \\
\text { mning } \\
\text { reques } \\
\text { ting, } \\
\text { agitati } \\
\text { ng, } \\
\text { ackno } \\
\text { wledg } \\
\text { ing, } \\
\text { entrea } \\
\text { ting }\end{array}$ \\
\hline $\begin{array}{l}\text { Constable } \\
\text { Afonja }\end{array}$ & $\begin{array}{l}\text { when he heard that } \\
\text { Aderopo the prince }\end{array}$ & $\begin{array}{l}\text { conceptual } \\
\text { conative }\end{array}$ & $\begin{array}{l}\text { conceptual } \\
\text { conative silence }\end{array}$ & $\begin{array}{l}\text { The kings and their } \\
\text { families are well }\end{array}$ & $\begin{array}{l}\text { Defen } \\
\text { ding }\end{array}$ \\
\hline
\end{tabular}


VS Publications

Alford Council of International English \& Literature Journal(ACIELJ)

Impact Factor:4.401(SJIF)An International Peer-Reviewed English Journal www.acielj.com

ISSN:2581-6500

\begin{tabular}{|c|c|c|c|c|c|}
\hline & was the murderer & & & $\begin{array}{l}\text { respected. And they } \\
\text { should therefore not be } \\
\text { referred to as being } \\
\text { evil. To therefore say } \\
\text { that the prince is behind } \\
\text { the killing in the land is } \\
\text { a taboo should not be } \\
\text { mentioned in words }\end{array}$ & \\
\hline $\begin{array}{l}\text { Funmi } \\
\text { Ransom- } \\
\text { Kuti }\end{array}$ & $\begin{array}{l}\text { When she went to the } \\
\text { British Office to visit } \\
\text { Lord Sebastin. }\end{array}$ & Phatic & Importance & $\begin{array}{l}\text { Silence as feeling of } \\
\text { importance-with Funmi } \\
\text { Ransom-Kuti when she } \\
\text { visits Lord Sebastin. } \\
\text { Lord Sebastin keeps } \\
\text { quiet. He rises and sits } \\
\text { without uttering a } \\
\text { word, making several } \\
\text { gestures and eye } \\
\text { movements. }\end{array}$ & $\begin{array}{l}\text { Pridin } \\
\text { g, } \\
\text { ridicul } \\
\text { ing, }\end{array}$ \\
\hline Agbekoya & $\begin{array}{l}\text { On the farm when } \\
\text { questioned by } \\
\text { Waziri about the } \\
\text { rash treatment } \\
\text { they got in Ibadan }\end{array}$ & Speech act & Avoidance & $\begin{array}{l}\text { When asks about the } \\
\text { dehumanizing } \\
\text { treatment they get in } \\
\text { Ibadan and how badly } \\
\text { his life has turned } \\
\text { despite his bright } \\
\text { beginning; he keeps } \\
\text { quiet, pretends to be } \\
\text { busy and later walks } \\
\text { away. }\end{array}$ & $\begin{array}{l}\text { Avoid } \\
\text { ing, } \\
\text { conde } \\
\text { mning } \\
\text {, }\end{array}$ \\
\hline $\begin{array}{l}\text { Lord } \\
\text { Sebastin }\end{array}$ & $\begin{array}{l}\text { In a board meeting } \\
\text { with Waziri and other } \\
\text { British personnel. }\end{array}$ & Phatic & Disregard & $\begin{array}{l}\text { Cultural difference. } \\
\text { Lord Sebastin who is } \\
\text { obviously a younger } \\
\text { person to Waziri refers } \\
\text { to him as a Danny boy } \\
\text { and wouldn't respond } \\
\text { to his greeting for a } \\
\text { grunt 'humnnn'. }\end{array}$ & $\begin{array}{l}\text { Disre } \\
\text { gardin } \\
\mathrm{g},\end{array}$ \\
\hline Waziri & In the British office & Emotive & Anger & $\begin{array}{l}\text { Silence is considered } \\
\text { crucial in the } \\
\text { conversational situation }\end{array}$ & $\begin{array}{l}\text { Summ } \\
\text { oning, } \\
\text { dema }\end{array}$ \\
\hline
\end{tabular}


VS Publications

Alford Council of International English \& Literature Journal(ACIELJ)

Impact Factor:4.401(SJIF)An International Peer-Reviewed English Journal

www.acielj.com

Vol-3,Issue-2 ,2020

ISSN:2581-6500

\begin{tabular}{|l|l|l|}
\hline $\mid$ & $\mid \begin{array}{l}\text { this evident in the nding, } \\
\text { silence deployed when } \\
\text { Waziri considers the } \\
\text { image of the queen of } \\
\text { England. This a is a } \\
\text { marker of disrespect for } \\
\text { the British imperialist } \\
\text { as the emotive silence } \\
\text { is broken by all heads } \\
\text { turned towards the } \\
\text { direction of Waziri's } \\
\text { gaze (the queen's } \\
\text { picture). Eloquent } \\
\text { silence here is deployed } \\
\text { for both emotive and } \\
\text { phatic function what } \\
\text { will soon be revealed in } \\
\text { the movie. }\end{array}$ \\
\hline
\end{tabular}

The instances highlighted are some of the instances where eloquent silence were used in the movie with such silent functions as phatic, conative, referential and so on. The conative function was recurrent because of the prince's elevated position a highly educated and revered prince. The acts generated are instantiated on such contextual triggers as shared situational knowledge, shared cultural knowledge and shared beliefs.

The bias in the movie is contextualized as purely African where people that possess political and sometimes religious power are accorded so much regard as to exclude them from punishment or shroud them from being publicly humiliated while every ordinary citizen that erred or conceived to have erred in the movie was punished. The paper explains that the modern act of impunity to political office holders is not new but adapted from the traditional African judicial system. The judicial system of bias is made evident in the chronicle of Babalfa and his revelation that Ifa is all knowing. In the extract:

Agara doesn't wrestle one before it trips Tembeleku has come to terms with danger It surely knows he nature of danger

It is not unfamiliar with hazard

That which divines for the tortoise who is friend's with the tiger and also with the bush rat

it kills at home and kills on the farm

Tembelekuhas come to terms with danger It surely knows the nature of danger It is not unfamiliar with hazard 
VS Publications

Alford Council of International English \& Literature Journal(ACIELJ)

Impact Factor:4.401(SJIF)An International Peer-Reviewed English Journal

www.acielj.com

Vol-3,Issue-2, 2020

ISSN:2581-6500

\subsection{Conclusion}

If the traditional culture of impunity in the African judicial system is well understood especially in the chronicles of Ifa and its reason for excluding some families especially the royal lineage from punishments, it is then that the explication political rulers and unfair justice between the poor and the rich; the governed and the government; the lords and the subjects in the modern judicial system would be understood and resolved.

Afolayan's October $1^{\text {st }}$ isn't just a movie about revenge and imperialist saga, it is also gender sensitive as it reveals the vulnerability of women in the chauvinistic African society where a man (Father Dawlin) did wrong but was avenged on six able virgins. Hence, the researcher intends to do a further study.

It should be emphasized that the visual of the movie gives additional pragmatic narrativity which give additional pragmatic import.

\section{References:}

[1]AbimbolaW.Iwapele: The Concept of Good Character in Ifa Corpus(Oxford: Oxford University Press)

[2]AbiodunOlayiwole and Folajimi (2017).The Poetics of Demythologization in KunleAfolayan'sThe Figurine

Legon Journal of Humanities [3]AdewoyeO.( 1987) 'Proverbs As a Vehicle of Juristic Thought',Obafemi Awolowo University Law Journal, 1987, $3 \& 4$.
[4]Driberg J. (1998)'The African Conception of Law', Journal of the African Society, p. 34

[5]Elias T.O.(1952)The Nature of African Customary

LawManchester: Manchester University Press

[6]Tannen D. (1986). That's Not What I Meant. Ballantine Books.

[7]Ekwuazi, H. (1987). Film in Nigeria. Ibadan: Moonlight Publishers

[8]Umeh F.E.(1989).The Courts and Administrative of Law in Nigeria.Enugu: Fourth Dimension [9]Oladipo, O. (2002).The Third Way in African Philosophy: Essays in Honour of KwasiWiredu, (Ibadan: Hope Publications Ltd,) [10]Idowu, B. (1967) 'The Yoruba Spirit World' Orita: Ibadan Journal of Religious Studies, Vol. 1 No. 1, June, 1967.

[11]Idowu, B. (1967). Olodumare, God in Yoruba Belief.London: Heinemann Publishers.

[12]Interviews with Elderly Informants in Ibadan (2018). Issues surrounding the concepts of Ifa (A. Titilope, Interviewer)

[13]MbitiJ.

(1987). 'African Religion and Philosophy', cited by OmoniyiAdewoye in Proverbs as a Vehicle of Juristic Thought, [14]Obafemi Awolowo University Law Journal, 1987, 3\&4.

[15]Mbiti, J. S.(1978).Introduction to African Traditional Religions. Nairobi: Heinemann Educational Books. Delano, I.O, op.cit 
VS Publications

Alford Council of International English \& Literature Journal(ACIELJ)

Impact Factor:4.401(SJIF)An International Peer-Reviewed English Journal www.acielj.com

[16]Okonkwo, C.O. (1980).

Introduction to Nigerian

Law.London: Sweet and Maxwell.

[17]October $1^{\text {st }}$. (2014). Directed

by KunleAfolayan. Nigeria.

Golden Effects 